\title{
Minimum TI4085D Interlock Setpoint at 1.0 GPN Sludge-Only Feed Rate and 14,000 PPM TOC (U)
}

by

A. S. Choi

Westinghouse Savannah River Company

Savannah River Site

Aiken, South Carolina 29808

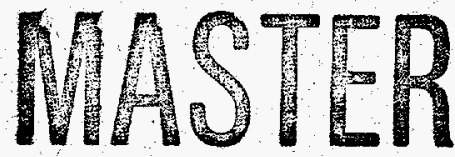

DOE Contract No. DE-AC09-89SR18035

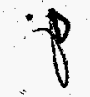

This paper was prepared in connection with work done under the above contract number with the U.S.

Department of Energy. By acceptance of this paper, the publisher and/or recipient acknowledges the U.S.

Government's right to retain a nonexclusive, royalty-free license in and to any copyright covering this paper, along with the right to reproduce and to authorize others to reproduce all or part of the copyrighted paper. 


\section{DISCLAMMER}

Portions of this document may be illegible in electronic image produets. Images are produced from the best available original document. 


\section{DISCLAIMER}

This report was prepared as an account of work sponsored by an agency of the United States Government. Neither the United States Government nor any agency thereof, nor any of their employees, makes any warranty, express or implied, or assumes any legal liability or responsibility for the accuracy, completeness, or usefulness of any information, apparatus, product, or process disclosed, or represents that its use would not infringe privately owned rights. Reference herein to any specific commercial product, process, or service by trade name, trademark, manufacturer, or otherwise does not necessarily constitute or imply its endorsement. recommendation, or favoring by the United States Government or any agency thereof. The views and opinions of authors expressed herein do not necessarily state or reflect those of the United States Government or any agency thereof.

This report has been reproduced directly from the best available copy.

Available to DOE and DOE contractors from the Office of Scientific and Technical Information, P.O. Box 62, Oak Ridge, TN 37831; prices available from (615) 57.6-8401.

Available to the public from the National Technical Information Service, U.S. Department of Commerce, 5285 Port Royal Road, Springfield, VA 22161. 
WSRC-TR-96-0357-TL

November 5, 1996

MINIMUM TI4085D INTERLOCK SETPOINT AT

1.0 GPM SLUDGE-ONLY FEED RATE AND 14,000 PPM TOC (U)

Distribution:

M. N. Brosee, 704-S

S. F. Piccolo, 704-S

J. F. Ortaldo, 704-S

M. J. Montini, 704-S

J. T. Carter, 704-25S

R. E. Edwards, 704-25S

W. A. Wagner, 704-27S

J. E. Owen, 704-30S

T. B. Calloway, 704-30S

J. P. Schwenker, 704-35S

D F. Gehr, 704-35S

W. A. Mangiante, 992-1W

L. M. Papouchado, 773-A

E. W. Holtzscheiter, 773-A

M. J. Plodinec, 773-A

L. F. Landon, 704-T

C. T. Randall, 704-T

R. A. Jacobs, 704-T

T. K. Snyder, 704-T

A. S. Choi, 704-1T (2)

SRTC Records，773-52A (4) 


\section{WESTINGHOUSE SAVANNAH RIVER COMPANY SAVANNAH RIVER TECHNOLOGY CENTER}

WSRC-TR-96-0357-TL

(Revision 0)

November 5, 1996

Keywords: DWPF Melter, TI4085D, Feed Rate, TOC, LFL

Retention Period: Permanent

M. N. Brosee, Manager

Defense Waste Processing Facility

High Level Waste Management Division

Attention: S. F. Piccolo, 704-S

\section{MINIMUM TI4085D INTERLOCK SETPOINT AT 1.0 GPM SLUDGE-ONLY FEED RATE AND 14,000 PPM TOC (U)}

Based on the attached E-7 calculations by A. S. Choi, it is recommended that the minimum melter vapor space temperature interlock be set to shut off feeding at an indicated temperature (TI4085D) of $570{ }^{\circ} \mathrm{C}$. The attached calculations indicate that at this temperature interlock the actual gas temperature in the melter vapor space will remain at or above $400^{\circ} \mathrm{C}$, which in turn assures that in the event of a $3 \mathrm{X}$ off-gas surge the peak concentration of combustible gases will remain below $60 \%$ of the lower flammability limit in the Off-Gas Condensate Tank. Note that the minimum temperature interlock setpoint of $570^{\circ} \mathrm{C}$ is valid only when the total organic carbon level in the melter feed is not higher than $14,000 \mathrm{ppm}$, all due to formate carbon only, at a feed rate not higher than $1.0 \mathrm{GPM}$, and when the air purges to FIC3221A and FIC-3221B are maintained at or above 850 and $250 \mathrm{lb} / \mathrm{hr}$, respectively. Please address any questions concerning the calculations to A. S. Choi@7-7729.

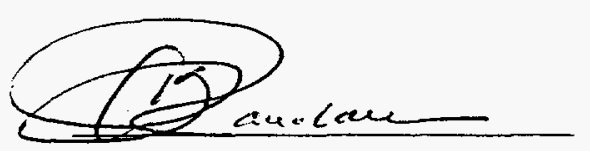

C. T. Randall, 704-T

Authorized Derivative Classifier

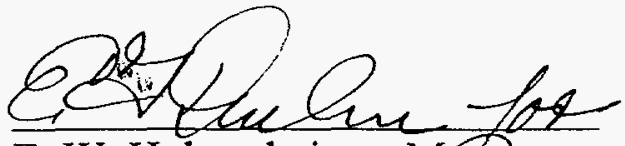

E. W. Holtzscheiter, Mangger SRTC - DWPT Section 
WSRC-TR-96-0357

Keywords: DWPF Melter, TI4085D, Feed Rate, TOC, LFL

Retention Period: Permanent

\section{MINIMUM TI4085D INTERLOCK SETPOINT AT \\ 1.0 GPM SLUDGE-ONLY FEED RATE AND \\ 14,000 PPM TOC (U)}

November 5, 1996

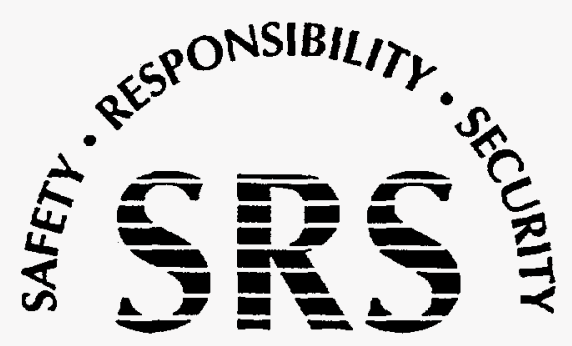

SAVANNAH RIVER SITE

Alexander S. Choi

Defense Waste Processing Technology

Savannah River Technology Center

Westinghouse Savannah River Company

Aiken, SC 29808 


\section{SUMMARY}

DWPF-Engineering requested that SRTC determine the minimum indicated melter vapor space temperature that must be maintained in order to minimize the potential for off-gas flammability during a steady sludge-only feeding operation at $1.0 \mathrm{GPM}$ containing $14,000 \mathrm{ppm}$ total organic carbon. The detailed scope of this request is described in the technical task request, HLW-DWPF-TTR-960092 (DWPT Activity \#DWPT-96-0065). In response to this request, a dynamic simulation study was conducted in which the concentration of flammable gases was tracked throughout the course of a simulated $3 \mathrm{X}$ off-gas surge using the melter off-gas (MOG) dynamics model. The results of simulation showed that as long as the melter vapor space temperature as indicated on TI4085D is kept at $570{ }^{\circ} \mathrm{C}$ or higher, the peak concentration of combustible gases in the melter off-gas system is not likely to exceed $60 \%$ of the lower flammability limit (LFL). The minimum TI4085D of $570{ }^{\circ} \mathrm{C}$ is valid only when the air purges to FIC3221A and FIC3221B are maintained at or above 850 and $250 \mathrm{lb} / \mathrm{hr}$, respectively. All the key bases and assumptions along with the input data used in the simulation are described in the attached E-7 calculation note.

\section{BACKGROUND}

The pretreated slurry feed to the DWPF melter contains a large quantity of formate salts and, during a coupled feed operation, aromatic carbon residues as well. The formate and high-boiling aromatic carbon compounds are easily decomposed during the early stages of the calcination step to form mainly $\mathrm{CO}, \mathrm{CO}_{2}$ and $\mathrm{H}_{2}$. These calcine gases and volatile organic species in the feed such as $\mathrm{C}_{6} \mathrm{H}_{6}$ and $\mathrm{C}_{6} \mathrm{H}_{5} \mathrm{OH}$ then enter the melter vapor space where they are oxidized in the presence of excess oxygen before exiting the melter. During normal operation, the melter vapor space is kept at a temperature high enough to achieve nearly complete combustion, thus posing no flammability concerns downstream. However, cold cap instabilities caused by the inherent nature of slurry feeding occasionally lead to a momentary surge in steam and calcine gas flows into the vapor space, thereby resulting in a sharp increase in melter pressure and a significant decrease in gas temperature. It is during these transient periods when the combination of higherthan-normal quantities of combustible gases, lower-than-normal gas temperature, and shorter-than-normal gas residence time in the melter vapor space leads to a significant reduction in combustion efficiency, thereby increasing the potential for forming a flammable gas mixture downstream especially after nearly all the steam is condensed out in the Quencher. Therefore, one of the key safety requirements in the operation of DWPF melter off-gas system is to ensure that the concentration of flammable gases downstream of the Quencher remains below $60 \%$ of the LFL under the worst-case operating conditions. 
Here, the worst-case operating conditions are defined as when off-gas surges occur due to cold cap instabilities while all the critical operating variables are kept at their maximum or minimum allowable values. Those critical operating variables affecting off-gas flammability are the feed rate, carbon content in the feed, melter vapor space temperature, and air flows for combustion and dilution. ${ }^{1}$ Currently, DWPF has interlocks on feeding when the total air flow to the melter (FIC3221A) or that to the backup film cooler (FIC3221B) drops below 850 or $250 \mathrm{lb} / \mathrm{hr}$, respectively. So, when both feed rate and carbon content in the feed are fixed, and the air flows to FIC3221A and FIC3221B are kept at their respective minimum interlock values, then there must be a minimum allowable melter vapor space temperature under steady state operating conditions below which the peak concentration of combustibles gases after the Quencher exceeds $60 \%$ of the LFL during an off-gas surge with a given profile as a function of time.

\section{OBJECTIVE}

The objective of the attached calculations was precisely to determine the minimum allowable indicated melter vapor space temperature (TI4085D) when the feed rate is fixed at 1.0 GPM, and the total carbon content is also fixed at $14,000 \mathrm{ppm}$ on an aqueous slurry basis, all due to formate carbon only, so that it can be assured that the potential for off-gas flammability is minimized under the worst-case operating conditions.

\section{BASES}

The MOG dynamics model was used to simulate the worst-case operating conditions for off-gas flammability under which the minimum TI4085D of $570{ }^{\circ} \mathrm{C}$ was determined. Before running the MOG dynamics model, it was necessary to run another model, called 4-stage cold cap model, which is used to calculate the composition and flow rates of steam and noncondensable gases produced during calcining and melting. The key characteristics of these models are described briefly in page 5 of the attached calculation note, and all the bases and input data used in the model calculations are described in pages 6,7 , and 9 to 13 . One of the key bases used was a $3 X$ off-gas surge profile described in page 9 , and up to 3 times normal noncondensable off-gas flows were indeed observed earlier during pilot-melter runs. ${ }^{2,3}$ Subsequently, it was specified in the Basic Data Report that the design basis transient melter off-gas flow rate be 3 times normal for the flammability control purposes. ${ }^{4}$ 


\section{REMARKS ON TI4085D}

It is important to point out that the minimum melter vapor space temperature of $570^{\circ} \mathrm{C}$ as indicated on TI4085D is not the same as the actual gas temperature in the vapor space and that it is the latter that counts in the combustion calculations. Currently, the temperature of the DWPF melter vapor space is measured with the use of a thermocouple enclosed in a thermowell and, due to thermal radiation impinging on the thermowell, the measured temperature is typically 150 to $200{ }^{\circ} \mathrm{C}$ higher than the actual gas temperature during a steady state feeding operation. Furthermore, it is nearly impossible to detect any thermal changes occurring in the melter vapor space during brief off-gas surge periods with the use of TI4085D due to high thermal inertia of the thermowell. As a result, a correlation was developed earlier to predict the actual gas temperature from the measured steady state vapor space temperature, ${ }^{5}$ and the changes occurring to the actual gas temperature during brief transient periods were predicted within the MOG dynamics model, and subsequently used to assess their impact on the combustion efficiency.

\section{REFERENCES}

1. Choi, A. S., "Maximum Total Organic Carbon Limits at Different DWPF Melter Feed Rates (U)," WSRC-TR-95-0294 (Revision 1), January 15, 1996.

2. Hull, H. L., "Trip Report Battelle-Pacific Northwest Laboratory Slurry-Fed Melter Test May 17-21, 1982," DPST-82-718, July 20, 1982.

3. Hull, H. L., "Trip Report Battelle-Pacific Northwest Laboratory Slurry-Fed Melter Test June 14-23, 1982," DPST-82-1008, November 15, 1982.

4. Basic Data Report, DPSP-80-1033, Volume 1, April 1985.

5. Choi, A. S., "Prediction of Melter Off-Gas Explosiveness (U)," WSRC-TR-90-346 (Revision 0), January 22, 1992. 


\section{ATTACHMENTS}

Calculation No. X-CLC-S-00069 


\section{Calculation Cover Sheet}

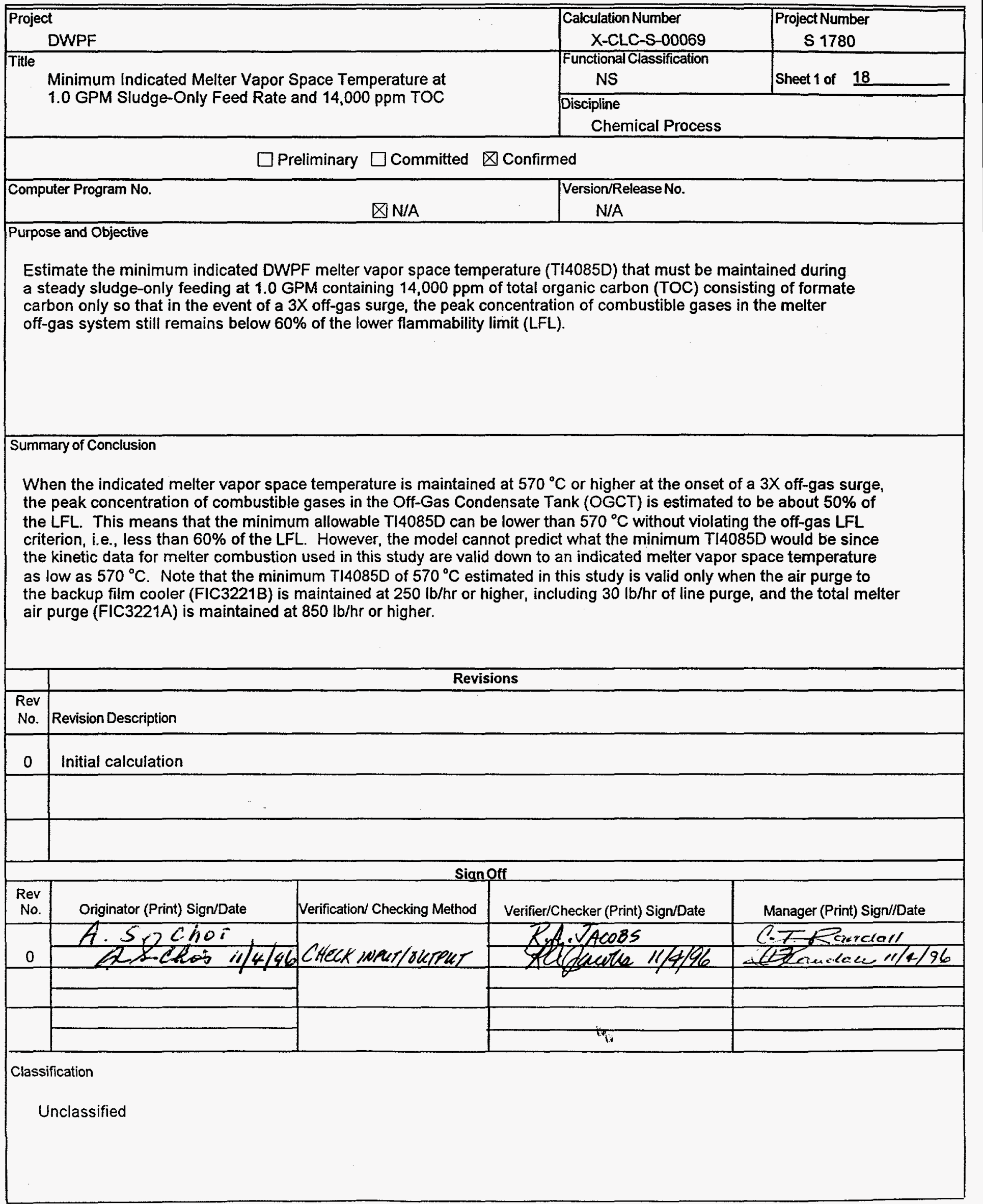




\section{Calculation Continuation Sheet}

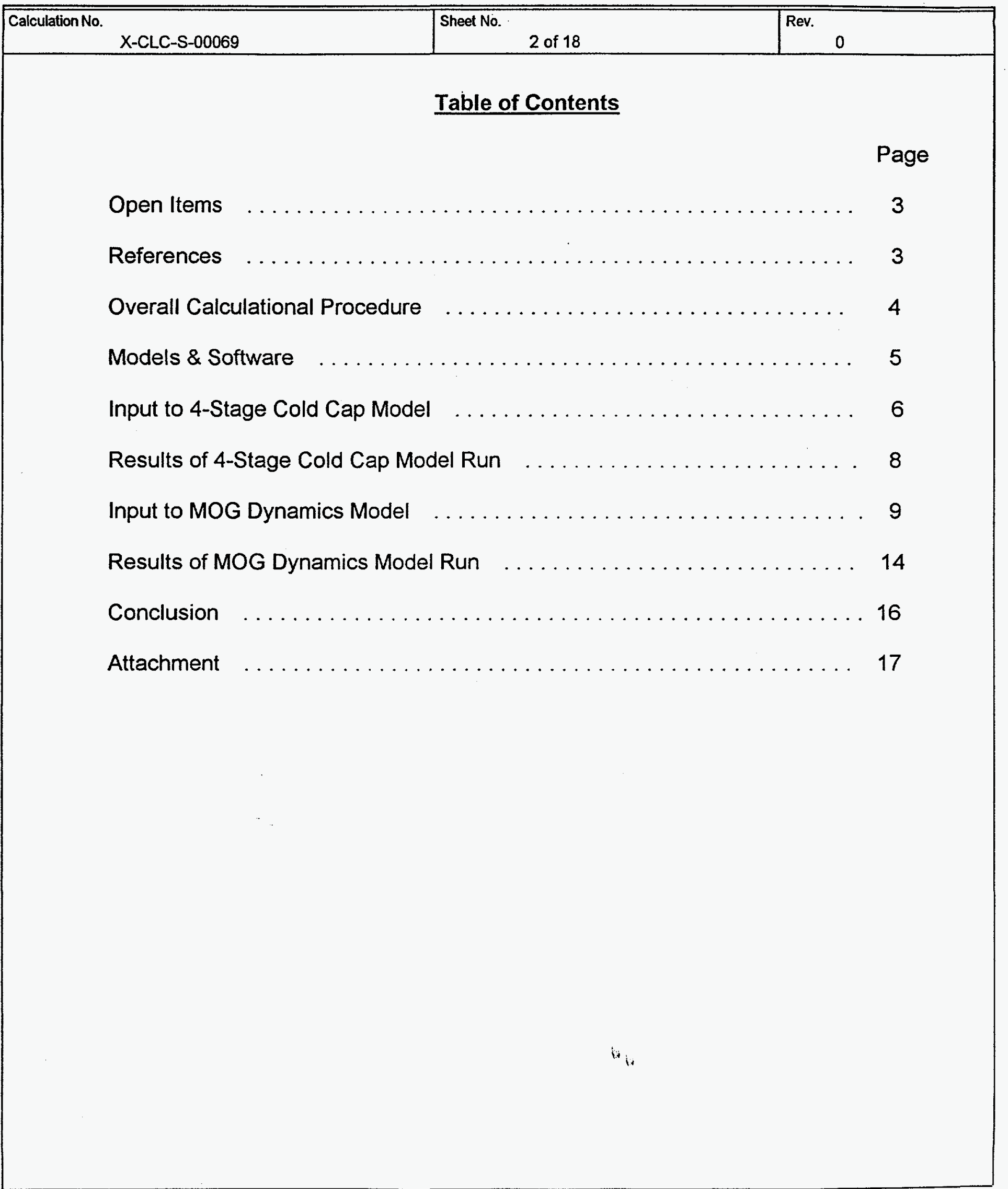




\section{Calculation Continuation Sheet}

\begin{tabular}{|l|l|l|l|l|}
\hline Calculation No. & Sheet No. & Rev. & \\
& X-CLC-S-00069 18 & 0 \\
\hline
\end{tabular}

\section{Open Items}

This calculation has no open items.

\section{References}

1. Choi, A. S., "Maximum Total Organic Carbon Limit for DWPF Melter (U)," WSRC-TR-95-0119 (Revision 0), March 13, 1995.

2. Dynamic Analysis Program Version 2.81 User Manual, Bechtel, Inc., San Francisco, March 1988.

3. Choi, A. S., and Iverson, D. C., "Methods of Off-Gas Flammability Control for DWPF Melter Off-Gas System at Savannah River Site," WSRC-MS-95-0455, October 1995.

4. Flynn, H. E., Morris, A. E., and Carter, D., "Staged Thermodynamic Model of Glass Fusion Based on SOLGASMIX-PV," Advances in the Fusion of Glass, Am. Cer. Soc., pp 28.1-28.14 (1988).

5. Plante, E. R., Bonnell, D. W., and Hastie, J. W., "Experimental and Theoretical Determination of Oxide Glass Vapor Pressures and Activities," Advances in the Fusion of Glass, Am. Cer. Soc., pp 26.1-26.18 (1988).

6. Choi, A. S., "Prediction of Melter Off-Gas Explosiveness (U)," WSRC-TR-90-346 (Revision 0), January 22, 1992.

7. Choi, A. S., "Material Balance Tables for the DWPF Coupled Feed Flowsheet with Batch One Sludge (U)," WSRC-TR-93-203 (Revision 0), August 19, 1993.

8. Choi, A. S., et al., "Summary of Campaigns SGM-9 and SGM-10 of the DWPF Scale Glass Melter," DPST-88-626, December 15, 1988. 


\section{Calculation Continuation Sheet}

\begin{tabular}{|l|l|l|l|}
\hline Calculation No. & Sheet No. 4 of 18 & Rev. & 0 \\
\hline
\end{tabular}

\section{Overall Calculational Procedure}

The off-gas flammability in the melter off-gas treatment system is determined largely by the combustion efficiency in the melter vapor space and the air flows available for dilution downstream. At a given feed composition and air purge into the melter vapor space, the combustion efficiency is in turn determined by the gas temperature and residence time in the melter vapor space. The indicated melter vapor space temperature (T14085D) is measured in the vapor space thermowells and, during feeding, is typically 150 to $200^{\circ} \mathrm{C}$ higher than the corresponding actual gas temperature due to thermal radiation impinging on the walls of a thermowell. Thus, the prediction of melter off-gas flammability during an upset period requires accurate dynamic information on all these variables just mentioned, and the DWPF melter off-gas (MOG) dynamics model is used to do just that, i.e., to predict the overall dynamic responses by the system, including pressures, gas temperatures and flows, throughout the duration of an upset.

For a melter feed containing only the formate carbon, all combustible gases to be burned in the melter vapor space are produced in the cold cap, and the composition of the calcine gases must be estimated before the MOG dynamics model can be run. To do this, another model, called the 4-stage cold cap model, is used. This model predicts the compositions of both glass and calcine gases, and the calcine gas predictions were validated against only the formic acid flowsheet data. So, the off-gas results obtained with a melter feed for the nitric acid flowsheet are adjusted to match the formic acid flowsheet results, which makes the calculated composition of combustible gases conservatively high.

The overall calculational procedure for determining the minimum indicated melter vapor space temperature for the off-gas flammability control can be summarized as follows:

1. Calculate the flow rates of calcine gases from a given nitric acid flowsheet feed using the 4-stage cold cap model, and adjust the off-gas results to reflect those obtained under the formic acid flowsheet conditions.

2. Assume a value for T14085D, and run the MOG dynamics model until a steady state is established using the calculated composition and flow rates of calcine gases and the assumed indicated melter vapor space temperature.

3. At time zero, initiate a $3 X$ off-gas surge, and check if the calculated peak concentration of combustible gases downstream of the Quencher is just less than $60 \%$ of the LFL.

4. If higher, assume a larger value for T14085D, and repeat the process from Step \#2. If much lower, assume a smaller value for T14085D, and repeat the same process. 


\section{Calculation Continuation Sheet}

\begin{tabular}{|c|c|c|}
\hline $\begin{array}{l}\text { Calculation No. } \\
\quad \text { X-CLC-S-00069 }\end{array}$ & 5 of 18 & Rev. \\
\hline
\end{tabular}

\section{Models \& Software}

A brief summary of the two models used in the calculation of the minimum TI4085D is given next. The important conclusions and findings which were uncovered during the validation of these models are attached at the end of this calculation note.

The DWPF MOG dynamics model:

- predicts the dynamic responses of both primary and backup DWPF melter off-gas systems under various upset conditions.

- calculates 5-component transient mass and energy balances from first principles.

- simulates all major MOG system hardware, including $22 \mathrm{PI}$ controllers and 26 valves, and the distributed control system (DCS) software logic.

- employs a 2-step global mechanism for aromatic carbon combustion and empirical oxidation kinetics of $\mathrm{CO}$ and $\mathrm{H}_{2}$ in the melter vapor space [1].

- is built on Dynamic Analysis Program (DAP) Version 2.81, a proprietary dynamic simulation software developed by Bechtel, Inc. [2].

- was validated against DWPF Cold Run data [3].

The 4-stage cold cap model:

- calculates the compositions of glass and calcine gases from a given melter feed composition.

- assumes that calcination and melting of nonvolatile feed components proceed in 4 distinct stages and all gaseous and solids products in each stage are at thermodynamic equilibrium, i.e., total Gibbs free energy is at a minimum.

- accounts for solution nonideality among melt phases.

- is built on STGSOL Version 2.5, a steady state, multistage, countercurrent chemical equilibrium software developed at University of Missouri at Rolla using SOLGASMIX algorithm [4].

- uses the Gibbs free energy database for complex liquids developed at the National Institute of Standards and Technology (NIST) [5].

- was validated using pilot meltêr run data $[3,6]$. 


\section{Calculation Continuation Sheet}

\begin{tabular}{|l|l|l|}
\hline \hline Calculation No. & Sheet No. 6 of 18 & Rev. \\
\hline
\end{tabular}

\section{Input to 4-Stage Cold Cap Model}

The composition of the reference DWPF melter feed given in Stream 60 of Reference 7 was used as the input to the model with the following adjustments:

1. No aromatic carbon residues were fed.

2. All minor feed components not containing the following 18 elements were excluded:

$$
\text { C, H, O, N, S, Si, Na, Li, Fe, Al, Mn, Ca, Mg, Ni, K, B, Cu, Cs }
$$

3. The feed rates of all formate salts were increased by a factor of 2.3 so that the total formate carbon content in the feed was increased from 6,370 to $14,000 \mathrm{ppm}$ based on an aqueous slurry mass basis.

4. The feed rates of all feed components, including $\mathrm{H}_{2} \mathrm{O}$ were increased by a factor of 1.11 so that the slurry feed rate was increased from 0.9 to $1.0 \mathrm{GPM}$ or 599 to $698 \mathrm{lb} / \mathrm{hr}$.

The final melter feed after adjustment had the following characteristics:

$$
\begin{aligned}
& \text { total slurry feed rate }(\mathrm{GPM})=1.0 \\
& \qquad(\mathrm{lb} / \mathrm{hr})=697.7 \\
& \text { total solids content }(\mathrm{w} / \%)=47.0 \\
& \text { free } \mathrm{H}_{2} \mathrm{O}(\mathrm{lb} / \mathrm{hr})=370.7 \\
& \text { estimated specific gravity }=1.3934 \\
& \text { formate salts }(\mathrm{lb} / \mathrm{hr})=59.7 \\
& \text { total formate, } \mathrm{F}(\mathrm{molar})=1.63 \\
& \text { nitrate salts }(\mathrm{lb} / \mathrm{hr})=20.6 \\
& \text { total nitrate; } \mathrm{N}(\mathrm{molar})=0.48 \\
& \text { feed redox, } \mathrm{F}-\mathrm{N} \text { (molar) }=1.14
\end{aligned}
$$

The actual input to the 4-stage cold cap model was based on this adjusted melter feed, and is given in Table 1. 


\section{Calculation Continuation Sheet}

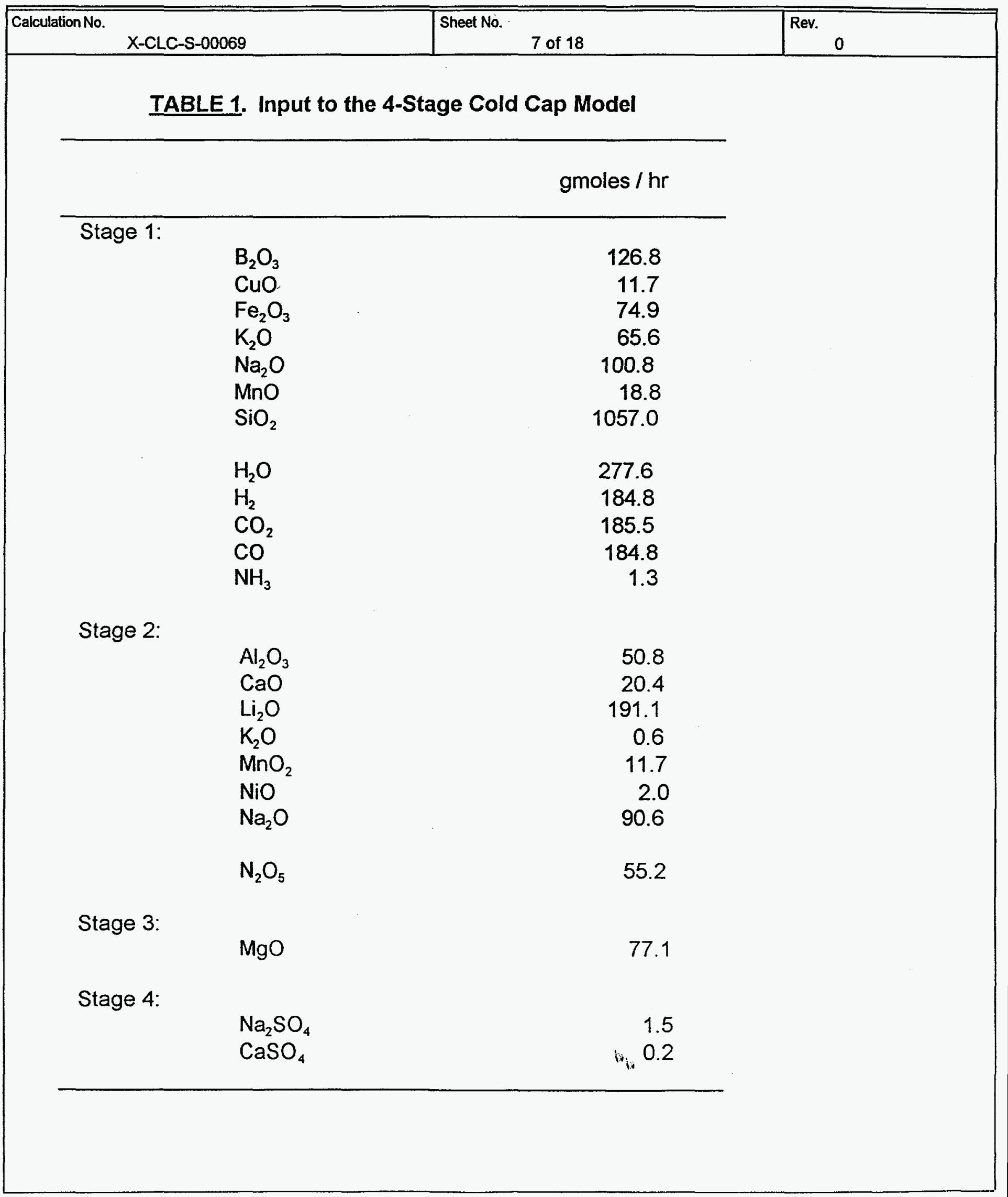




\section{Calculation Continuation Sheet}

\begin{tabular}{|c|c|c|}
\hline $\begin{array}{l}\text { Calculation No. } \\
\\
\text { X-CLC-S-00069 }\end{array}$ & Sheet No. & $\begin{array}{ll}\text { Rev. } & \\
& 0\end{array}$ \\
\hline \multicolumn{3}{|c|}{ Results of 4-Stage Cold Cap Model Run } \\
\hline \multicolumn{3}{|c|}{$\begin{array}{l}\text { Table } 2 \text { shows the calculated flow rates of calcine gases before and after adjustment. } \\
\text { Clearly, the 4-stage cold cap model predicted that at equilibrium combustible gases } \\
\text { such as } \mathrm{CO} \text { and } \mathrm{H}_{2} \text { are oxidized by consuming all available } \mathrm{O}_{2} \text {. In this study, however, } \\
\text { the predicted } \mathrm{CO} / \mathrm{CO}_{2} \text { molar ratio of } 0.056 \text { was adjusted to match the measured value } \\
\text { of } 0.146 \text { with a formic acid flowsheet feed, and the molar flow rate of } \mathrm{H}_{2} \text { was adjusted } \\
\text { to equal } 1 / 2 \text { of the sum of those of } \mathrm{CO} \text { and } \mathrm{CO}_{2} \text {. As a result, the adjusted off-gas flow } \\
\text { contains much higher concentrations of combustible gases, which is a direct result of } \\
\text { the assumption in this study that nitrates do not play an oxidizing role in the gas-phase } \\
\text { reactions as they do for the solid-phase reactions, thereby impacting the glass redox. } \\
\text { This is a major conservative assumption affecting the outcome of off-gas flammability } \\
\text { calculations using the MOG dynamics model. }\end{array}$} \\
\hline
\end{tabular}

TABLE 2. Calculated Cold Cap Off-Gas Flow Rates.

\begin{tabular}{crr}
\hline species & $\begin{array}{r}\text { before adjustment } \\
(\mathrm{lb} / \mathrm{hr})\end{array}$ & $\begin{array}{r}\text { after adjustment } \\
(\mathrm{lb} / \mathrm{hr})\end{array}$ \\
\hline calcine gases & & \\
$\mathrm{CO}_{2}$ & & 31.34 \\
$\mathrm{CO}$ & 34.01 & 2.91 \\
$\mathrm{H}_{2} \mathrm{O}$ & 1.21 & 11.09 \\
$\mathrm{H}_{2}$ & 16.05 & 0.82 \\
$\mathrm{~N}_{2}$ & 0.27 & 3.44 \\
$\mathrm{O}_{2}$ & 3.44 & 5.38 \\
total & 0.00 & 54.98 \\
free $\mathrm{H}_{2} \mathrm{O}$ & 54.98 & 370.7 \\
\hline
\end{tabular}




\section{Calculation Continuation Sheet}

\begin{tabular}{|c|c|c|}
\hline Calculation No. & Sheet No. 9 of 18 & Rev. \\
\hline X-CLC-S-0006 & & 0 \\
\hline
\end{tabular}

\section{Input to MOG Dynamics Model}

In order to minimize any potential for off-gas flammability, the MOG dynamics model is run under the worst-case operating conditions, and they are:

1. The conservative cold cap off-gas flow rates given in Table 2 are taken as the normal feed rates to the melter vapor space reactor.

2. The air purge rate to the backup off-gas film cooler (FIC-3221B) is maintained at the low-flow interlock of $220 \mathrm{lb} / \mathrm{hr}$ plus $30 \mathrm{lb} / \mathrm{hr}$ line purge.

3. The total melter air purge rate to the FIC-3221A is maintained at the low-flow interlock of $850 \mathrm{lb} / \mathrm{hr}$, including $60 \mathrm{lb} / \mathrm{hr}$ air purge to the cameras that is purged back out to the cell.

4. The oxidation of $\mathrm{CO}$ and $\mathrm{H}_{2}$ in the melter vapor space is assumed to follow the apparent first-order kinetics in the presence of abundant $\mathrm{O}_{2}$ supply several times in excess of the stoichiometric requirement:

$$
\begin{aligned}
& -r_{\mathrm{CO}}=k_{\mathrm{CO}} C_{\mathrm{CO}} \\
& -r_{\mathrm{H} 2}=k_{\mathrm{H} 2} C_{\mathrm{H} 2}
\end{aligned}
$$

where $\mathrm{r}^{\prime} \mathrm{s}$ are the reaction rates in $\mathrm{lbmoles} / \mathrm{ft}^{3} / \mathrm{sec}, \mathrm{C}^{\prime} \mathrm{s}$ the concentrations in $\mathrm{lbmoles} / \mathrm{ft}^{3}$, and $\mathrm{k}^{\prime} \mathrm{s}$ the first-order rate constants in $\mathrm{sec}^{-1}$ of the form:

$$
k=k_{b} \exp \left(-E_{a} / R T\right)
$$

where $k_{0}$ is the preexponential factor in sec $^{-1}$, and $E_{a}$ the activation energy in Btu/lbmole. The rate parameters given in Table 3 were derived from the SRTC's 9th Scale Glass Melter campaign data $[1,8]$, and subsequently used in the model.

5. The $3 X$ off-gas surge is assumed to proceed as follows [1]:

At time zero, the flow rates of both condensable and noncondensable gases given in Table 2 are increased by $300 \%$ instantly, then immediately decreased linearly to $150 \%$ of the normal values during the first 1 minute of the surge, and further decreased linearly to the normal values during the next 7 minutes. 


\section{Calculation Continuation Sheet}

\begin{tabular}{|c|l|l|}
\hline Calculation No. & Sheet No. 10 of 18 & Rev. \\
\hline X-CLC-S-00069 & & 0 \\
\hline
\end{tabular}

Input to MOG Dynamics Model (Cont'd)

6. The estimated air inleakage to the melter was included in the calculation of the gas residence time in the melter vapor space, but was not considered as a source for dilution or combustion air in the LFL calculations.

7. The melter pressure control air flow was not considered as a source for dilution or combustion air in the LFL calculations.

8. The tuning constants used for all 22 major controllers are given in Table 4. Refer to the following table to identify the corresponding DCS controller for each controller number used in the model.

Model Controller \# DCS Controller I.D.

\begin{tabular}{ll}
\hline 1 & TIC3682 \\
2 & PIC3521 \\
3 & PDIC3526 \\
4 & TDIC4300 \\
5 & SIC3585 \\
6 & TIC3620A \\
7 & SIC4324 \\
8 & TIC3386 \\
9 & TDI3400 \\
10 & FIC3691 \\
11 & TIC3395 \\
12 & for model use only \\
13 & FIC3221A \\
14 & FIC3534 \\
15 & backup exhauster outlet flow \\
16 & FIC3590 \\
17 & FIC4344 \\
18 & FIC4340 \\
19 & TIC3501A \\
20 & FIC3595 \\
21 & TIC3421 \\
22 & FIC3221B \\
\hline
\end{tabular}




\section{Calculation Continuation Sheet}

\begin{tabular}{|c|c|c|}
\hline $\begin{aligned} \text { Calculation No. } & \\
& \text { X-CLC-S-00069 }\end{aligned}$ & $\begin{array}{l}\text { Sheet No. } \\
\\
11 \text { of } 18\end{array}$ & $\begin{array}{ll}\text { Rev. } & \\
& 0 \\
\end{array}$ \\
\hline \multicolumn{3}{|c|}{ Input to MOG Dynamics Model (Cont'd) } \\
\hline \multicolumn{3}{|c|}{$\begin{array}{l}\text { TABLE 3. Apparent First-Order Rate Parameters for } \mathrm{CO} \text { and } \mathrm{H} 2 \text { Oxidatic } \\
\text { the DWPF Melter Vapor Space }\left(\mathrm{T}_{\text {gas }}>395^{\circ} \mathrm{C}\right)\end{array}$} \\
\hline & $\begin{array}{c}k_{0} \\
\left(\sec ^{-1}\right)\end{array}$ & $\begin{array}{c}\mathrm{E}_{\mathrm{a}} \\
(\mathrm{Btu} / \mathrm{lbmole})\end{array}$ \\
\hline $\mathrm{CO}$ & 1021.8 & 19974 \\
\hline $\mathrm{H}_{2}$ & 9756.6 & 25170 \\
\hline
\end{tabular}




\section{Calculation Continuation Sheet}

\begin{tabular}{|c|c|c|c|c|c|c|c|c|c|}
\hline Calculation No. & \multicolumn{2}{|c|}{-CLC-S-00069 } & & \multicolumn{3}{|c|}{ Sheet No. } & & \multicolumn{2}{|l|}{$\begin{array}{r}\text { Rev. } \\
0\end{array}$} \\
\hline \multicolumn{10}{|c|}{ Input to MOG Dynamics Model (Cont'd) } \\
\hline & & & I G I & C O N & OLLER & DATA & $S U M M A R$ & & \\
\hline \multirow{3}{*}{$\begin{array}{l}\text { CONT. } \\
\text { NO. }\end{array}$} & MODE & COUT & SETPT & GAIN & DERIV & ZERO & COUTLL & OINT & ANTI \\
\hline & $-\cdots$ & $\cdots$ & $\cdots$ & $\cdots$ & $\cdots \cdot$ & $\cdots$ & - ..... & -..... & RESET \\
\hline & TYPE & ACTION & CIN & RSET & SAMPLE & RANGE & COUTUL & MANIN & HINDUP \\
\hline \multirow[t]{2}{*}{1} & AUTO & .000 & 375.00 & 1.000 & .000 & 200.00 & .000 & .020 & YES \\
\hline & $p+I$ & REVERSE & 310.95 & 2.500 & 3.000 & 600.00 & 1.000 & .000 & \\
\hline \multirow[t]{2}{*}{2} & AUTO & .767 & -5.00 & 2.250 & .000 & -25.00 & .000 & .000 & YES \\
\hline & $P+1$ & DIRECT & -4.99 & .900 & .250 & 5.00 & 1.000 & .767 & \\
\hline \multirow[t]{2}{*}{3} & AUTO & .765 & -4.00 & 2.000 & .000 & -10.00 & .000 & .000 & YES \\
\hline & $\mathrm{p}+1$ & REVERSE & -4.00 & 5.000 & 1.000 & 10.00 & 1.000 & .765 & \\
\hline \multirow[t]{2}{*}{4} & AUTO & .446 & 10.00 & 1.000 & .000 & .00 & .000 & .000 & YES \\
\hline & $P+1$ & DIRECT & 10.00 & 2.500 & 3.000 & 20.00 & 1.000 & .446 & \\
\hline \multirow[t]{2}{*}{5} & MAN & .405 & 400.00 & .500 & .000 & .00 & .010 & .000 & YES \\
\hline & $P+I$ & DIRECT & 529.55 & 2.000 & 1.000 & 800.00 & 1.000 & .405 & \\
\hline \multirow[t]{2}{*}{6} & MAN & .436 & 40.00 & 2.000 & .000 & .00 & .000 & .000 & YES \\
\hline & $p+1$ & REVERSE & 40.00 & 5.000 & 3.000 & 100.00 & 1.000 & .436 & \\
\hline \multirow[t]{2}{*}{7} & AUTO & .120 & 400.00 & .500 & .000 & .00 & .010 & .000 & YES \\
\hline & $P+1$ & DIRECT & 400.00 & 2.000 & 1.000 & 800.00 & 1.000 & .120 & \\
\hline \multirow[t]{2}{*}{8} & AUTO & .789 & 10.00 & 2.000 & .000 & .00 & .050 & .000 & YES \\
\hline & $P+I$ & REVERSE & 9.99 & 2.000 & 3.000 & 50.00 & 1.000 & .789 & \\
\hline \multirow[t]{2}{*}{9} & AUTO & .558 & 10.00 & 1.000 & .000 & .00 & .000 & .000 & YES \\
\hline & $P+1$ & DIRECT & 10.00 & 2.500 & 3.000 & 20.00 & 1.000 & .558 & \\
\hline \multirow[t]{2}{*}{10} & AUTO & .405 & 500.00 & 1.000 & .000 & .00 & .010 & .000 & YES \\
\hline & $P+I$ & DIRECT & 500.85 & 1.200 & .500 & 1400.00 & 1.000 & .405 & \\
\hline \multirow[t]{2}{*}{11} & AUTO & .477 & 10.00 & 2.000 & .000 & .00 & .050 & .000 & YES \\
\hline & $p+1$ & REVERSE & 10.00 & 2.000 & 3.000 & 50.00 & 1.000 & .477 & \\
\hline \multirow[t]{2}{*}{12} & AUto & .587 & 400.00 & 2.500 & .000 & .00 & .000 & .000 & YES \\
\hline & $p+1$ & DIRECT & 400.07 & .200 & 3.000 & 1000.00 & 1.000 & .587 & \\
\hline \multirow[t]{2}{*}{13} & AUTO & .187 & 960.00 & .300 & .000 & $b_{0.00}$ & .000 & .000 & YES \\
\hline & $P+I$ & DIRECT & 960.00 & 3.950 & .500 & 1750.00 & 1.000 & .187 & \\
\hline \multirow[t]{2}{*}{14} & MAN & .120 & 500.00 & .600 & .000 & .00 & .010 & .002 & YES \\
\hline & $P+I$ & DIRECT & .00 & .600 & .500 & 1400.00 & 1.000 & .120 & \\
\hline
\end{tabular}




\section{Calculation Continuation Sheet}

\begin{tabular}{|c|c|c|c|c|c|c|c|c|c|}
\hline \multicolumn{4}{|c|}{$\begin{array}{l}\text { Calculation No. } \\
\qquad \text { X-CLC-S-00069 }\end{array}$} & \multicolumn{3}{|c|}{ Sheet No. } & & \multicolumn{2}{|c|}{$\begin{array}{r}\text { Rev. } \\
0\end{array}$} \\
\hline \multicolumn{10}{|c|}{ Input to MOG Dynamics Model (Cont'd) } \\
\hline \multicolumn{10}{|c|}{ TABLE 4. Tuning Constants Used in MOG Dynamics Model (Cont'd) } \\
\hline \multicolumn{10}{|c|}{ D IGITAL } \\
\hline \multirow{3}{*}{$\begin{array}{l}\text { CONT. } \\
\text { NO. }\end{array}$} & MODE & Cout & SETPT & GAIN & DERIV & ZERO & COUTLL & OINT & ANTI \\
\hline & $\ldots$ & $\cdots$ & $\ldots$ & --- & $\cdots$ & $\ldots$ & -.... & ....... & RESET \\
\hline & TYPE & ACTION & CIN & RSET & SAMPLE & RANGE & COUTUL & MANIN & WINDUP \\
\hline \multirow[t]{2}{*}{15} & AUTO & .000 & 1100.00 & .500 & .000 & .00 & .000 & -.014 & YES \\
\hline & $P+1$ & DIRECT & 1386.91 & 2.000 & 3.000 & 2000.00 & 1.000 & .000 & \\
\hline \multirow[t]{2}{*}{16} & AUro & .530 & 367.00 & .500 & .000 & .00 & .000 & .000 & YES \\
\hline & $P+1$ & DIRECT & 367.16 & 5.000 & 3.000 & 500.00 & 1.000 & .530 & \\
\hline \multirow[t]{2}{*}{17} & MAN & .000 & 367.00 & .500 & .000 & .00 & .000 & .000 & YES \\
\hline & $P+1$ & DIRECT & .00 & 5.000 & 3.000 & 500.00 & 1.000 & .000 & \\
\hline \multirow[t]{2}{*}{18} & MAN & .000 & 367.00 & .500 & .000 & .00 & .000 & .000 & YES \\
\hline & $P+1$ & DIRECT & .00 & 5.000 & 3.000 & 500.00 & 1.000 & .000 & \\
\hline \multirow[t]{2}{*}{19} & MAN & .000 & 40.00 & 2.000 & .000 & .00 & .000 & .000 & YES \\
\hline & $P+I$ & REVERSE & 40.00 & 5.000 & 3.000 & 100.00 & 1.000 & .000 & \\
\hline \multirow[t]{2}{*}{20} & AUTO & .530 & 367.00 & .500 & .000 & .00 & .000 & .000 & YES \\
\hline & $P+I$ & DIRECT & 367.00 & 5.000 & 3.000 & 500.00 & 1.000 & .530 & \\
\hline \multirow[t]{2}{*}{21} & MAN & .000 & 350.00 & 1.000 & .000 & 200.00 & .000 & .000 & YES \\
\hline & $P+I$ & REVERSE & 200.00 & 2.500 & 3.000 & 600.00 & 1.000 & .000 & \\
\hline \multirow[t]{2}{*}{22} & AUTO & .179 & 430.00 & .300 & .000 & .00 & .000 & .000 & YES \\
\hline & $P+1$ & DIRECT & 430.00 & 3.950 & .500 & 1150.00 & 1.000 & .179 & \\
\hline
\end{tabular}




\section{Calculation Continuation Sheet}

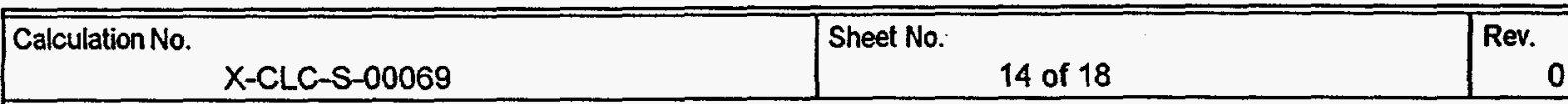

\section{Results of MOG Dynamics Model Run}

Figure 1 shows the results of the MOG dynamics model run with an indicated melter vapor space temperature (TI4085D) of $570^{\circ} \mathrm{C}$ at the onset of $3 X$ surge. After steam is condensed out in the Quencher, the concentration of combustible gases in the OGCT has peaked at $50 \%$ of the LFL about 1 minute into the surge. The actual gas temperature in the melter vapor space is at the minimum of about $260^{\circ} \mathrm{C}$ in less than 30 seconds into the surge.

FIGURE 1. Results of $3 X$ Surge Simulation at TI4085D $=570^{\circ} \mathrm{C}$ and $14,000 \mathrm{ppm}$ TOC (PIC3521: Gain $=2.25$, Reset $=0.015 ;$ FIC3691: Gain $=1.0$, Reset $=0.02$ )
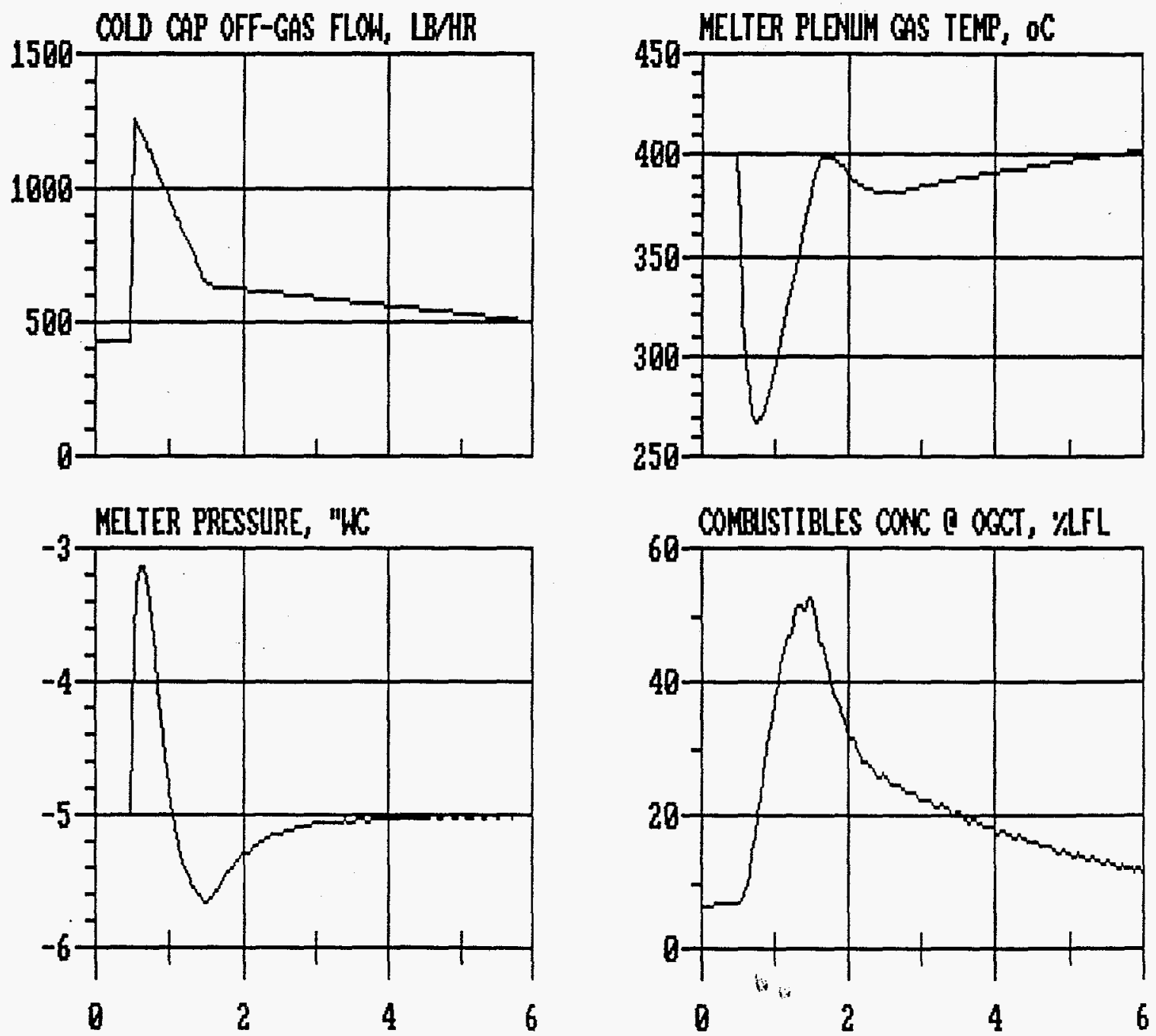

TIME IN MINUTES 


\section{Calculation Continuation Sheet}

\begin{tabular}{|c|c|c|c|}
\hline Calculation No. & Sheet No: & Rev. & 0 \\
\hline X-CLC-S-00069 18 & & 0 \\
\hline
\end{tabular}

\section{Results of MOG Dynamics Model Run (Cont'd)}

The MOG dynamics model was run again with the same value for TI4085D but with different tuning constants for PIC3521 and FIC3691. As shown in Figure 2, as the gain for PIC3521 was reduced from 2.25 to 1.0 , and the reset rate was increased from 0.015 to 0.083 repeats per second, the melter pressure peaked at a somewhat higher value, and oscillated more before restoring back to the setpoint. However, these tuning constants, which were used in earlier simulation runs [1], had no impact on the off-gas flammability.

FIGURE 2. Results of $3 X$ Surge Simulation at TI4085D $=570^{\circ} \mathrm{C}$ and $14,000 \mathrm{ppm}$ TOC (PIC3521: Gain = 1.0, Reset $=0.083 ;$ FIC3691: Gain $=0.6$, Reset $=0.01$ )
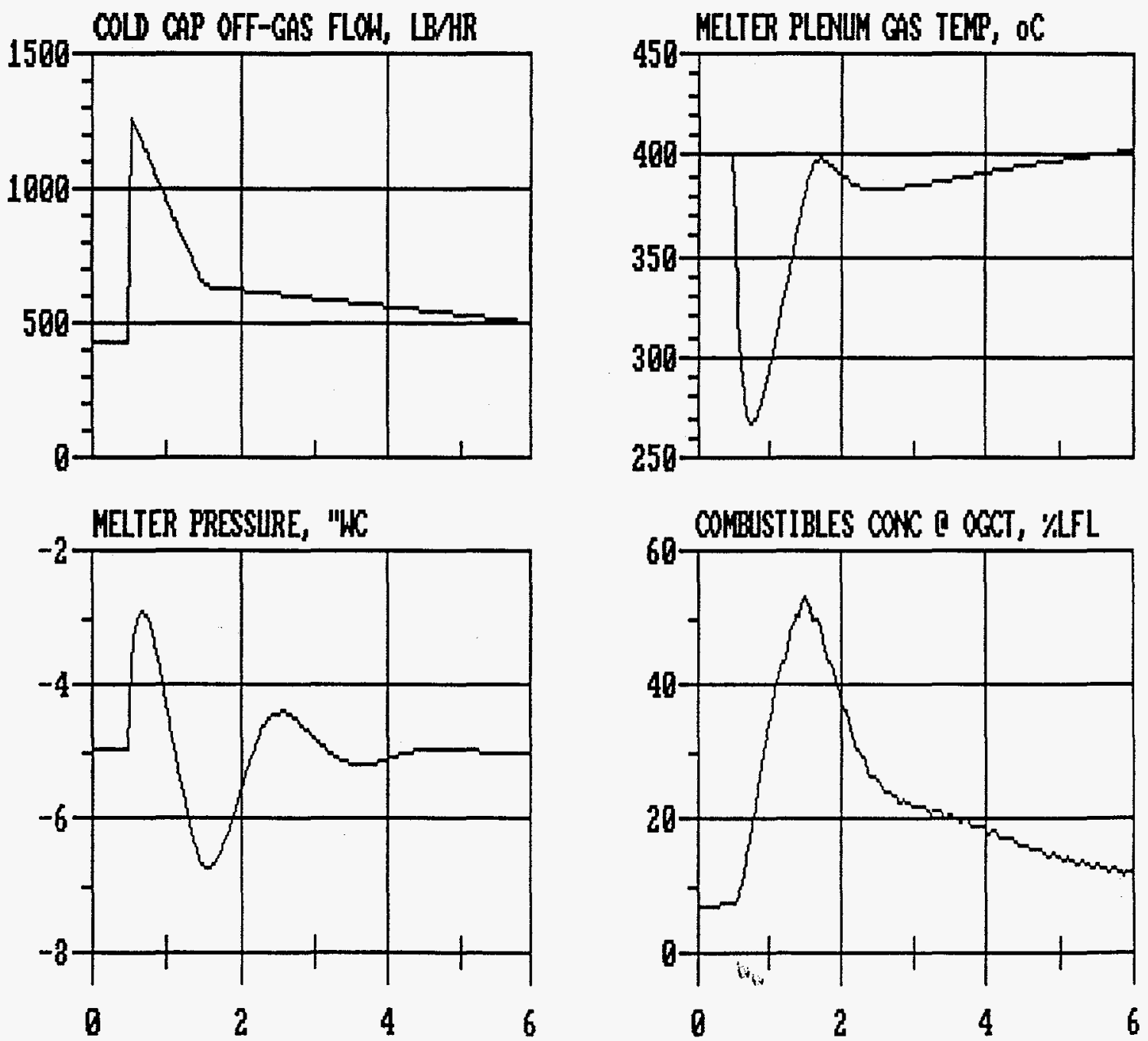

TIME IN MINUTES 


\section{Calculation Continuation Sheet}

\begin{tabular}{l|l|l|}
\hline Calculation No. X-CLC-S-00069 & Sheet No. 16 of 18 & Rev. \\
\hline Conclusion & \\
At the indicated melter vapor space temperature (TI4085D) of $570{ }^{\circ} \mathrm{C}$ and a nominal feed \\
rate of $1.0 \mathrm{GPM}$ containing 14,000 ppm TOC, the MOG dynamics model predicted that the \\
peak concentration of combustible gases in the OGCT is about $50 \%$ of the LFL during a $3 \mathrm{X}$ \\
off-gas surge. Due to conservative assumptions used in the two models, it is believed that \\
the indicated melter vapor space temperature (TI4085D) can be maintained at temperatures \\
somewhat lower than $570^{\circ} \mathrm{C}$ without exceeding the $60 \% \mathrm{LFL}$ criterion. However, the model \\
cannot predict what the minimum allowable value for TI4085D would be, since the first-order \\
rate parameters given in Table 3 are valid down to gas temperatures as low as $395^{\circ} \mathrm{C}$ which \\
is approximately equal to $570^{\circ} \mathrm{C}$ indicated melter vapor space temperature. It is important to \\
note that the minimum TI4085D of $570^{\circ} \mathrm{C}$ is based on the minimum air purges to FIC $3221 \mathrm{~A}$ \\
and FIC $3221 \mathrm{~B}$ of at least 850 and $250 \mathrm{lb} / \mathrm{hr}$, respectively.
\end{tabular}




\section{Calculation Continuation Sheet}

\begin{tabular}{|l|l|l|}
\hline Calculation No. & Sheet No. 17 of 18 & Rev. \\
X-CLC-S-00069 & & 0 \\
\hline
\end{tabular}

\section{Attachment}

\section{Validation of 4-stage cold cap \& MOG dynamics models}

The 4-stage cold cap model was validated against SRTC's pilot-melter run data obtained with the formic acid flowsheet feeds $[3,6]$. As shown in Table 5, the overall agreement between the measured and calculated iron redox ratio in glass and off-gas compositions for feeds containing only the formate carbon is reasonably good. For feeds containing both formate and aromatic carbons, however, the model tends to overpredict the efficiency of gas-phase oxidation reactions in the cold cap mainly due to the assumption that upon entering the cold cap, the aromatic carbon residues are instantaneously decomposed to $\mathrm{CO}$ and $\mathrm{H}_{2}$ and participate in the cold cap equilibrium reactions instantly by virtue of their low decomposition temperatures.

In an effort to make the model conservative from the off-gas flammability standpoint, the decomposition products of aromatic carbon residues are no longer allowed to participate in the cold cap reactions, except to consume available $\mathrm{O}_{2}$ to show their reducing effects on glass. Instead, they will undergo oxidation reactions in the melter vapor space along with the cold cap equilibrium products of formate decomposition in the presence of excess $\mathrm{O}_{2}$.

Recently, the 4-stage cold cap model was run under the nitric acid flowsheet conditions by simulating the DWPF Waste Qualification Run WP-16 with HM-type simulated feed which contained $34,500 \mathrm{ppm}$ formate $(\mathrm{F})$ and $30,000 \mathrm{ppm}$ nitrate $(\mathrm{N})$ for a F-N molar difference of 0.37 . As shown in Table 5 , the iron redox ratio in glass predicted by the model was 0.06 , while the measured ratio was less than 0.01 , although the analytical detection limit is known to be about 0.035 . Although not shown, the model predicted virtually no $\mathrm{CO}$ and $\mathrm{H}_{2}$ in the cold cap off-gas under the nitric acid flowsheet. Unfortunately, no off-gas data were available to compare, and the oxidizing effects of nitrates in the feed have not been incorporated into the 4-stage cold cap model. This makes the concentrations of combustible gases predicted by the model very conservatively high.

The MOG dynamics model was validated against both steady state and transient data taken during DWPF cold runs in 1995 [3]. The model was calibrated first using the data taken during melter idling. The calibrated model was then validated against three sets of steady state data, each at different feed rates, and the agreement between the data and the model was excellent [8]. The model was also validated against a set of transient data obtained during the flushing of melter feed tube \#1 just prior to the initiation of the feeding. Again, the overall agreement between the data and the model was reasonably good [3]. 
Calculation Continuation Sheet

\begin{tabular}{|c|c|c|c|c|}
\hline \multicolumn{2}{|c|}{$\begin{aligned} & \text { Calculation No. } \\
& \text { X-CLC-S-00069 } \\
&\end{aligned}$} & \multicolumn{2}{|c|}{$\begin{array}{ll}\text { Sheet No. } & 18 \text { of } 18 \\
\end{array}$} & \multirow[t]{2}{*}{\begin{tabular}{|ll} 
Rev. & \\
& 0 \\
\end{tabular}} \\
\hline TABLE : & \multicolumn{3}{|c|}{ Results of 4-Stage Cold Cap Model Validation } & \\
\hline $\begin{array}{l}\text { Feed } \\
\text { Carbons }\end{array}$ & $\begin{array}{c}\text { Flowsheet } \\
\text { Type }\end{array}$ & $\begin{array}{c}\text { Glass Redox } \\
\text { \& Off-Gas }\end{array}$ & $\begin{array}{c}\text { Data } \\
(\mathrm{lb} / 1,0\end{array}$ & $\begin{array}{c}\text { Model } \\
000 \text { lb glass) }\end{array}$ \\
\hline Formate & Formic Acid & $\begin{array}{c}\mathrm{Fe}(\mathrm{II}) / \mathrm{Fe}(\mathrm{III}) \\
\mathrm{CO} \\
\mathrm{CO}_{2} \\
\mathrm{H}_{2}\end{array}$ & $\begin{array}{c}0.24 \\
7.7 \\
92.0 \\
\text { N/A }\end{array}$ & $\begin{array}{l}0.35 \\
8.6 \\
85.9 \\
2.3\end{array}$ \\
\hline $\begin{array}{l}\text { Formate } \\
\text { Aromatic }\end{array}$ & Formic Acid & $\begin{array}{c}\mathrm{Fe}(\mathrm{II}) / \mathrm{Fe}(\mathrm{III}) \\
\mathrm{CO} \\
\mathrm{CO}_{2} \\
\mathrm{H}_{2}\end{array}$ & $\begin{array}{r}0.55 \\
18.5 \\
116.0 \\
3.0\end{array}$ & $\begin{array}{r}0.59 \\
8.5 \\
100.1 \\
2.7\end{array}$ \\
\hline $\begin{array}{l}\text { Formate } \\
\text { Aromatic }\end{array}$ & Nitric Acid & $\begin{array}{c}\mathrm{Fe}(\mathrm{II}) / \mathrm{Fe}(\mathrm{III}) \\
\mathrm{CO}, \mathrm{CO}_{2}, \mathrm{H}_{2}\end{array}$ & $\begin{array}{r}<0.01 \\
\text { no da }\end{array}$ & $\begin{array}{l}0.06 \\
\text { ata to compare }\end{array}$ \\
\hline
\end{tabular}

